$<$ 特別講演 $>$

\author{
炎症とマクロフアージ・リンパ球 \\ 林秀男 \\ 熊本大学医学部第 1 病理学教室
}

坐長; 柚 木一 雄

鹿巟島大学医学部

附属腄瘍研究施設

周知のよ5に, 炎症においては, 各種の白血球が順 ついで, これら natural mediator のなかで, 単球 (マクロファージ) 亜型 $\left(\mathrm{I}_{a}+\right.$ と $\mathrm{I}_{a}$-を比較), $\mathrm{T}, \mathrm{B}$ を追って反応局所に動員（遊出）し，それぞれの機能 を発揮するが, とくに注目すべきことは, 単球（マク

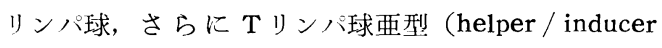
ロファージ）やリンパ球の亚型の遊出とその動態であ phenotype と suppressor/cytotoxic phenotype を比 る。この動態のちがいは，それぞれの炎症の生物学的 較）をそれぞれ seletiveに遊出（遊走）させる因子 特徴と関連すると思われる。

演者はまず，われわれが炎症局所（主としてimmunologically-mediated inflammation を対象とした) から分離, 精製したいくつかの natural mediator と を明らかにするににもに，これらの因子の局所活性と 覀型細胞反応との相関を説明する。このよ5な研究 は, in vivo 細胞反応の分子病理学的な解析への一の方向と考えられる。

各種白血球の遊走（遊出）の関係を総括的に述べる。

シンホジゥム I

「造血微小環境——構造と機能」

\author{
司会のととば \\ 関正 利 \\ 放射線医学研究所生理病理 \\ 山田英 雄 \\ 名古屋大学医学部内科
}

\section{はじめに}

最近数年間に従来の定説の修正を迫る二つの重要な 発見が，造血幹細胞についてなされた。第一は脾コ口
ニーを形成する幹細胞 (CFU-s) についてで, 移植后 $7 \sim 9$ 日に見られるコロニーの大部分は, 限定された 自己再生能しか持たない単一分化能幹細胞に由来する 
こと，一方 10 日目以降に出現するコロニーは極めて増 殖力の眭盛な多分化能幹細胞由来であるという事であ る。

第二に多分化能幹細胞からどの系の幹細胞を生ずる かは, 完全に確率的な現象であることが培養実験によ つて主張されるに至り, Trentin の唱えた徴小環境に よる分化誘導の仮説が大きく摇らぐことなった。

しかしこれ等の事実も, 造血統御に関する微小環境 の意義を軽くするものではない。特定の系への分化が 確率的に起るとすれば，その系の細胞に対する生体側 の要求に応ずる為には, 局所における, より精密な統 御が必要となる筈であって, その解析は益々重要性を 増すこととなろう。この為には, 従来機能の面に重点 を置かれていた研究も、このあたりで構成要素（細胞 及び細胞問物質）との形態学的対応を計る必要がある と考えられる。これは本シンポジムを企画するに当っ
て，特に配慮した点の一つである。最近造血微小環境 研究の方法論は Dexter 培養法を始め, CFU-F コロ ニー法, 基質構成細胞の株化とそのクローニング等を 中心に著しく進展し, 造血幹細胞と基質細胞あるいは 基質細胞同志の相互作用, 更には基質細胞の保有する 諸物（コラーゲン，フロテオグリカン，各種糖蛋白体 など）の血球分化に及ぼす影響などが明らかされてき た。一方造血微小環境の研究は再.生不良性貧血や白血 病を中心に臨床分野においても活発な展開を見せ，疾 患の病態生理解明に有力なアプローチを提供しつつあ る。本シンポジウムにおいてはこの様なユニークかつ 優れた研究成果の数々が報告される予定である。

最後に, 今回のシンポジゥムで語られた諸知見は, 微小環境を理解する為の一里塚であつて, 今後益々研 究を樑化させねばならないことを強調して置きたい。

\section{1. 骨髄の微小環境}

坂 井 英 隆, 橋 本 紀 三 九州大学茵学部口腔病理

造血の微小環境とい5概念には erythropoietin, colony stimulating factor, lymphokire など humoral factor により造血を調節するものと，造血組織の間質 細胞が cell of cell contactにより直接造血細胞に影 響をおよぼす，とい52つの category があり，前者 は long-range の後者は short-range の造血調節機構 と理解されている。我々は造血組織の主要臟器である 骨髄について short-range の微小環境としての間質網 状構造の微細構造および造血細胞との関わりを骨髄の 個体発生学的見地から，また $\mathrm{Co}^{60} 1000 \mathrm{R}$ 照射後の回 復過程から，マウス大腿省を対照として追求した。

個体発生的には胎生19日例では骨䯣腔は紡錘形〜長 円形の核と多数の細長い胞体実起を有する細網細胞に 類似した細胞が多数存在し, 微細かつ徵密な網状構造 を形成していた。一部の細胞は胞体突起が互いに overlap し, 数所に juuctional complex を認め, 静 脈洞を形成しつつある所見より洞内皮細胞と考えた。 造血細胞はこの時期ではほとんど認められず，わずか に小型リンパ球様細胞を認めるのみであった。胎生 20 H例では明瞭な静脈洞が形成され，洞間の網状構造と 明らかに区別できた。洞間には細網細胞に類似した細
胞に加え明らかな貧食像を示す macrophage む誌め られた。造血細胞では小型リン゙球様細胞に加え, こ れよりやや大型の円型細胞もみられた。生後 1 H例で は造血は急激に高まり，洞間の網状構造は粗なものへ と変化し, 個々の間質細胞の胞体突起も減少してい た。造血細胞では明らかに系統を区別できる細胞も多 数出現していた。また間質細胞の胞体突起が胎生20日 例よりみられた大型の円形細胞をつつみ込む様な所見 を認めた。生後 2 日例では造血はさらに高まり，いわ ゆる血球座としての造血細胞特有の配置状態がみられ ない,とい5点を除けばほぼ成熟例に近い所見を古 し, 生後 5 日例ではほほ成熟例と同様の所見を呈して いた。

Co60照射例では照射後 3 日までに既存の造血細胞は ほぼ消失していた。照射後 3 日例では間質に核小体が 明瞭で腫大した核を有する細網細胞を認め，4 日例で は赤芽球糸，顆粒球糸細胞の小さな再生 colony を認 めた。またこれらの colony 中には macrophage を認 めた。 5 日例ではこれらの colony 中の細胞数の増加 を認めたが 6 日例より減少し，8 日例では再び消失し ていた。 
2.ママウス脱灭骨移植における造占し検討

森真 由 美

東京都養育院付属病院血液科

岁能道（造足細胞）は一般に兴組織内に存在してお り，異所性化骨がみられる場合に，その部位に造血組 織が㴓められる事も多い。崩に異常をきたすような聅 患では, 時に造血障害が認められる。また骨代謝に関 与するホルモンが造血に影響を与える事も知られてい る。このような事実から, 造血微小環境の一つとして, 霄組織及びそれに関連する間葉糸組織が何らかの役割 をはたしているのではないかと考え検討してみた。 方法：マウス大腿骨を脱灰し，同系マウスの筋肉队に 移植した。それを経時的にとり出し, 造骨, 他の間葉 系組織，基質と造血の関係を検討した。正常状態で飼 育したコントロール群における造骨と造血の関係, 省 及び他の間葉糸組織に影響を与えるとされる状態での 造血と造常の関係を主に形態的に検咕し, その関連を みると同時に, 造骨の過程で, 造血刺激因子の産生が みられないかどうかも検討した。
結果及び考察 :

正常コントロール群においては, 移植後 $2 \sim 3$ 週目 に軟骨細胞の形成がみられ，その部が䇰細胞に変わっ ていく時期に，造血が認められるようになる。Vit-D 欠乏, $\mathrm{Ca}$ 欠乏食で飼育すると, 間葉系組織の発生, 及び肖形成は非常に羊延し, 明確な造血鉴は 8 週後も 認められず, 組織化学上, 酸性么コ多糖類等の染色性 にも変化が認められた。コラーゲン線維に異常を与え るとされる lathyrogen の投与により間葉系組織の発 生に異常を拉こすと，造骨に障害が生じ, 造血巣の発生 むいくらかおさえられた。造血刺激因子に関しては, 移植 1 週後の組織からすでにその産生が認められた。

このような事から，造血栄が壮現する際には，造任 㮺が単独に岷現するのではなく, 他の間葉系組織の発 生分化及びその種々の構成成分の変動をともなって初 めて可能であると考えられる。

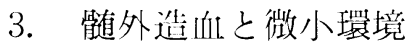

剖検例の組織学的観察-

平林紀男

多古屋大学部付属病院病理

造吹が系統発生，橭体発生のト:で管髄以外の場で始 まることを考えれば，髄外造血は造血の原型ともいえ る。又, 造血幹細胞と造血微小環境の概念が脾コロ二 一法の開発とその展開の中で形成された事実は, 䯣外 造血の研究が造血機構の研究に久くことのでききない 分野である事を示している。演者は剖検例で解外造血 の観察を進めているので, 造血微小環境を「䯣外造片 鉴への血球前駆細胞の定着とそれに続く増殖, 分化の 場」としてとらえ，以下の研究を行つた。

対象例と方法: 対象は, 1) 死産児, 新生児15例, 2 ）悪性腫瘍の骨転移 10 例，3）感染症 8 例，4） myelodysplastic syndromes 12 例, 5 ) 骨髄移植 17 例の脾, 肝, リンハ節, 腎である。赤芽球 ( $\mathrm{E}$ ) は八 モグロビン染色 (PAP法), 幼若顆粒球 (G) はnaph- thol AS-D chloroacetate esterase 染色 (Leder 法) で同定し, 臟器分布, 臓器内局在, 各造血系の増生: ターンを組織学的に観察した。

結果：1）は二系 $(\mathrm{E}>\mathrm{G})$ ともに肝, 慜, 脾の順に

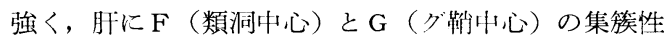
増生があり, 婜髄質の間質にも同様の造血符を認め る。 $\mathrm{E}$ と Gの混合性造血巣が肝グ䩪と粲門部結合織に 出現する例もある。2），3）の造血巣は脾の赤脾㖪と 肝の類洞にほほ限られ脾優位である。2）は $\mathrm{E}$ 主体で 島状集簇が強く，3）は $\mathrm{G}$ 主休で好中球と混在する。 4) では白血病非進展例を中心に G 主体の造血策が 4 臟器に及び， $\mathrm{E} に$ 加えて目核球や幼若好酸球の関与す る例もあり細胞構成が多彩である。Eの集簇性が弱く $\mathrm{G}$ に好中球混在の乏しいことが特徵で，リンバ節の門 
部や被膜での G の集簇性増生や肝グ鞘への G と E の出 現を㴓める例も少なくない。 5 ) は移植後 3 力月まで の脾臓に白脾髄領域の造血巣, $\mathrm{G}$ の集簇性増生, 三系
の混合性造造血策を認める例がある。

以上の造血様式の相違が如何なる造血機序の差を背 景に生ずるのかについて考察する。

\title{
4. 白血病と微小環境
}

\author{
吉田和子, 関 正利 \\ 放射線医学研究所生理病理研究部
}

マウスの白血病細胞は, 骨髄性白血病（顆粒球単球 系）の場合, 脾の赤脾髄とリンバロ胞, 肝のグリソン 氏に浸潤増殖し，赤白血病及び巨核芽球性白血病の場 合は, 赤脇髄, 肝小某に強い浸潤堌殖が認められた。 この様に病型により一定の浸潤傾向を示すことは, 白 I I.I.病性幹細胞も又正常の幹細胞と同様に増殖に好適な 環境を持つことを示唆している。

白血病細胞の in vitroでのコロニー形成能につい ては，種々検討されているが，すべての白血病につい て in vitvoでュロニー形成が可能である訳ではない。 我々の研究室で検討した限りでは, 数種類のコロニー 刺激因子を加えても in vitroでコロニーを形成しな い白血病細胞でも致死線量照射したマウスの脾にはコ ロニーを形成する。又，メチルセルロース法ではクラ スターしか形成しない細胞も in vitro CA 膜法（線維 芽細胞層からなる人丁的な造血の場) ではコロニーを 形成する。これらの結果は, in vitroでュ口二形成 能が認められない白血病細胞は, 何らかの未知の刺激
因子が必要なのか，あるいは“造血の場”が必要であ る事を示唆していると思われる。

これまでは白血病性幹細胞と“場”の関係について 述べてきたが，次に“造血の場”を構成している細胞 がその機能を維持したまま腫瘍化したと思われる症例 について述べる。

$\mathrm{X}$ 線照射により $\mathrm{C}_{3} \mathrm{H}$ マウスに誘発した骨髄増殖性 疾患（L-8313）は，脾細胞で同系マウスへ継代移植 可能である。この細胞は多分化能幹細胞の増殖に必要 と考えられている Interleukin-3, 赤芽球系堌殖刺激 因子 (B P A), 顆粒球系增粒刺激因子 (CSF) を産生 している事が証明された。 L-8313の細胞を移植され たマウスは，この細胞が産生する各種刺激因子に反応 して, CFUS, BFU-E, GM-CFU の顕著な増加が認 められる。この細胞を抗 Thy 1.2 抗体と補体で処理 して移植すると発症が著しく徉延することから T細胞 系に属する可能性が示唆される。

5. 付着性紏胞による造血幹細胞の調節

$$
\begin{gathered}
\text { 丹下 剛 } \\
\text { 東京大学医学部病理 }
\end{gathered}
$$

造㕰細胞の母細胞である造血幹細胞の増雃と分化は 造血因子と称される種々の物質の調節を受けていると 考えられている。最近は，それらの因子がどんな種類 の細胞によって産生されているかに興味がもたれつつ ある。演者は造血微小環境の仕組に強い関心をもつ一 人であるが，今回は，その機能的側面に関して，“付 着性細胞 (Adherent Cells) がもつ造血幹細胞 (CFUS, CFU-GM, BFU-E, FU--E) の増殖の抑制および 促進作用について述べてみたい。

近年, 多能性造血幹細胞である CFU-S の堌㫘が付
着性細胞によって抑制されることが指摘されている。 演者も数年間のマウス実験に打いて, CFU-S のアッ セイ法である脾コロニー法を行う際, 骨髄細胞とリン ハ節細胞を混合して同系照射マウスに静脈注射すると 脾コロニー形成の抑制を認めた。それはりンバ節中の 付着性細胞 (non-T, Ia, 放射線抵抗性, 熱易感受性, サイクロフォスファミド感受性）の作用と考えられ た。この抑制現象にはnon-H-2遺伝子が関与している と思わ机る以上:の事実は, 最近小川らが強調する久 トキャ久ティックモデルの概念に対立し，末熟な幹紐 
胞に対して特異的な抑制機構の存在を示唆する所見で ある。

次に, 最近, 武内が開発したヒト䇾髄由来の線維孫 細胞様細胞の株細胞（SH 株）の造血因子産生能を検 討する機会を得た。細胞は電顕像, コラーゲン産生能, フィブロネクチン産生能など線維芽細胞の特徵をも つ。この SH 株細胞の培養上清中には未熟な段階の赤 牙球前駆細胞に対する著しいBurst promoting Activity（BPA）を認めたが，顆粒球系に対する Colony Stimulating Activity (CSA)は弱く，また Interleu- kin 3(IL-3) 活性は認めていない。

さらに, 別の付着性細胞であるとト未梢血由来の単 球, マクロフアージ系株細胞の造血因子産生能につい ても目下，検剑中である。

\section{CFU-S: Colony Forming Unit-Spleen}

CFU-GM: Colony forming Unit-Granuloid and Macrophage

CFU-E: Colony Formiug Unit- Erythroid

BFU-E: Burst Forming Unit-Erythroid

6. マウス䇰䯣前脂肪細胞株の脂肪細胞化における in vitro 造血への影響

\author{
張ヶ谷健一, 中 村雅登 \\ 慶応義熟大学医学部病理
}

最近, 肖㖪間質に由来する前脂肪細胞株が報告され ており, これら胞株の脂肪化は体の他部のものと異な り脂肪合成においてインシュリンや糖質コルチュイド との反応性が異なることが報告されている。又, こ れらの細胞株が種々の面で造血細胞の増殖と分化に影 響を与えることが報告されている。初期のマウス骨䯣 培養系においては, 壁在細胞中の脂肪細胞の存在が in vitro に打ける造血幹細胞の増殖分化に不可欠なも のと考えられていたが，未だ，この事を確実に証明し た報告はない。むしろ, 前脂肪細胞の共通した機能と して CFUc 分化, 増殖への役割が多くの研究者によ って報告されている。我々は, マウス骨韨由来前脂肪 細胞株がコロニー刺激因子 (CSA) を産生し, 細胞が 飽和状態に達すると中性脂肪を合成し脂肪化すること を報告している。この細胞株の脂肪化は, 血清存在下 ではハイドロコーチゾン (HDC), あるいは, インシュ リンの添加により脂肪化が促進されブロモデオキジ
リジン（Brdu）の添加により脂肪化が阻止される。こ の前脂肪細胞株の脂肪細胞化と CSA 産生について検 剖すると, 線維芽細胞样形態を示す時期には活発な CSA産生を示すが, 脂肪細胞化するとCSA 産生が減 少する。上記の $\mathrm{HDC}, \mathrm{Brdu}$ などの脂肪化に影響を与. える薬剤を用いて検討しても，脂肪細胞化に伴って CSA 铸生の低下が認められた。又, CSA の減少は, 脂肪細胞化にともな5 CSA 阻害物質の産生によるも のではないことが明らかとなっている。培養期間のい ずれの時期においても, この細胞株は形成細胞, 混合 コロニー形成細胞, 初期赤血球系幹細胞などの造血翰 細胞に増殖刺激作用は示さず，むしろ，抑制的に働い ている。

以上のことは，肖髄前脂肪細胞の一部が脂肪細胞化 することにより造血への積極的な役割を失ならことを 意味し，造血の消失と骨髄の脂肪化という我々のよく 知っている現象をも説明する。

\title{
7. 長期培養法による人骨髄造血支持能の検討
}

堀田知光

名古屋大学医学部第 1 内科

近年, Dexter らによって莦髄の長期培養が可能と なり，造血細胞の維持，堌殖には壁付着細胞圓の存在 が重要であることが明らかにされている。この付着細
胞層は線維第細胞を主体に内皮細胞，マクロファー ジ，脂肪含有細胞などからなり，造血微小環境を形成 していると考えられている。本培膯法はヒ卜、の応月 
も誠みられ，骨髄造血向の病態解明に有力な研究手法を 提供するものと期待される。われわれは付着細胞層の 造血支持能を本培養系を挒いて調べることによって各 種造血障害における造血微小環境の変化を機能的な面 から解析した成績を報告する。

〔方法】採取した骨髄液より buffy-coat 細胞を 1 入 $10^{6} / \mathrm{ml}$ の濃度で $12.5 \%$ 牛胎児血清, $12.5 \%$ 馬血清, $10^{-6} \mathrm{M}$ hydrocortisone および $10^{-7} \mathrm{M} 2$-mercaptoethanol を含む $\alpha$ 培養液中に浮遊させ， $25 \mathrm{~cm}^{2}$ 組織培 養フラスコで $37^{\circ} \mathrm{C}, 5 \% \mathrm{CO}_{2}$ 下で静置培養を開始し た。毎週半量の培養液を交換し，付着細胞層が充分に 形成される $2 \sim 4$ 週目にフラス 全体に $1000 \mathrm{rad}$ の X線照射をし，全培盖液を除去したのち正常骨骾の非 貧食, 非付着細胞を新鮮培養液とともに加えて培養を 再開した。毎週の培養液交換時に回収される浮遊細胞
中の顆粓球系前駆細胞（CFU-GM）を測定した。

〔成績】正常付着細胞層に播種された CFU-GM は $1 \sim 2$ 週後に増加し, 次いで減少しはじめ 4〜5週で 最低となり, その後約半数例では再び軽度増加ないし 横ばいで維持された。急性白血病, 再生不良性貧向の 一部症例では付着細胞層の CFU-GM 支持能が低下し ていた。真性赤占球増加症，原発性骨髄線維症では匹： 常との差は認められなかって。

〔考按〕ヒトの長期背骾培養はまだ充分確立してお らず，改良すべき点も多いが，今回のわれわれの成䋶 は各種造血障害における管髄微小環境の機能障害の有 無を調べる力法として有用であることを示すとともに 再不貧の一部には造血微小環境障害が関与する可能性 を明らかにした。

\section{シンホジゥム II}

「ATL の基礎と臨床」

$$
\begin{aligned}
& \text { 司会りことば } \\
& \text { 花岡正男 } \\
& \text { 京都大学放スス研 } \\
& \text { 松元奏 }
\end{aligned}
$$

1975年, 臨床における新しい疾患の一つとして|成 人 T細胞壬血病 (ATL) |の概念が提晿されてから今 体で丁度10年老迎えるこの間，本邦の ATL 研究が 进った道は，世界に抢ける医学・生物学研究の歴史の なかでも，画期的な出来事の一つであったといえよ 5：ATLの概念の出現は, 臨休はもとより, 病理学に おける悪性りン，腫の分類をも摇るがしてきた。また 本症の地域集積性に闗する疫学的な研究は, in vitro での培養腫瘍細胞に打けるATLA (adult T-cell leukemia associated antigens)の発現やし型レトロウィ ルスの出現に関する発見，あるいは患者やその家族に おける抗 ATLA 抗体の発胃などと相诶って，本症が HTLV (human T-cell leukemia virus) の感染によ
ってもたらされる T細胞腫瘍であることを明らかにし てきたすなわち，医学・生物学の多くの分野の研究 者達が，それこそ先端の技術を駆使し，総力を結集し ての闘いであった その成果は, 着々とATLの全苋 を明らかにしつつはあるものの，末に多くの重要な課 題が残されていることも事実である。

今回のシンホジウムは, 多くの ATL 研究のなかか ら，本学会に関連すると思われるいくつかの話題を拾 って構成した。演題相互の間には, 必ずしも直接の䦌 連を罗出し難いものもあろらが, 過上10年の研究の歴 史のなかで，新しい去がりをホしながらも収斂しつつ ある ATL 研究の各分野での成績を整理すると共に, 将来の研究八の足捗りを探ろらとするものので女る 